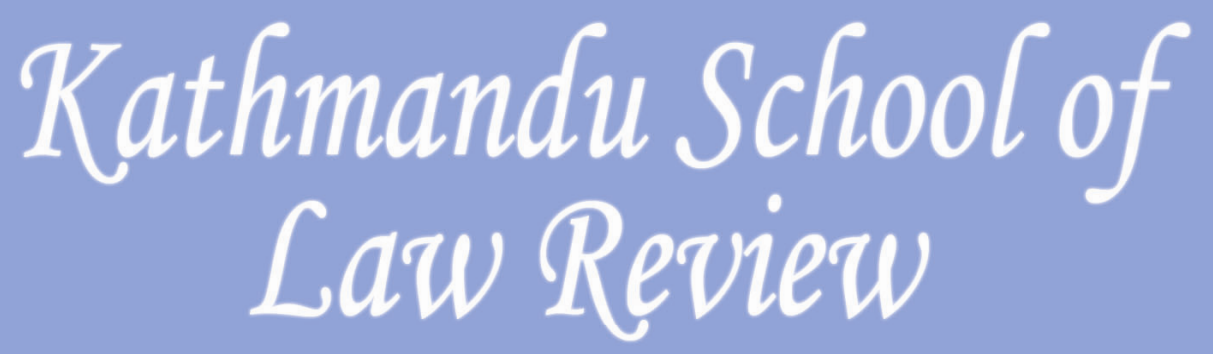

ISSN 2091-2110

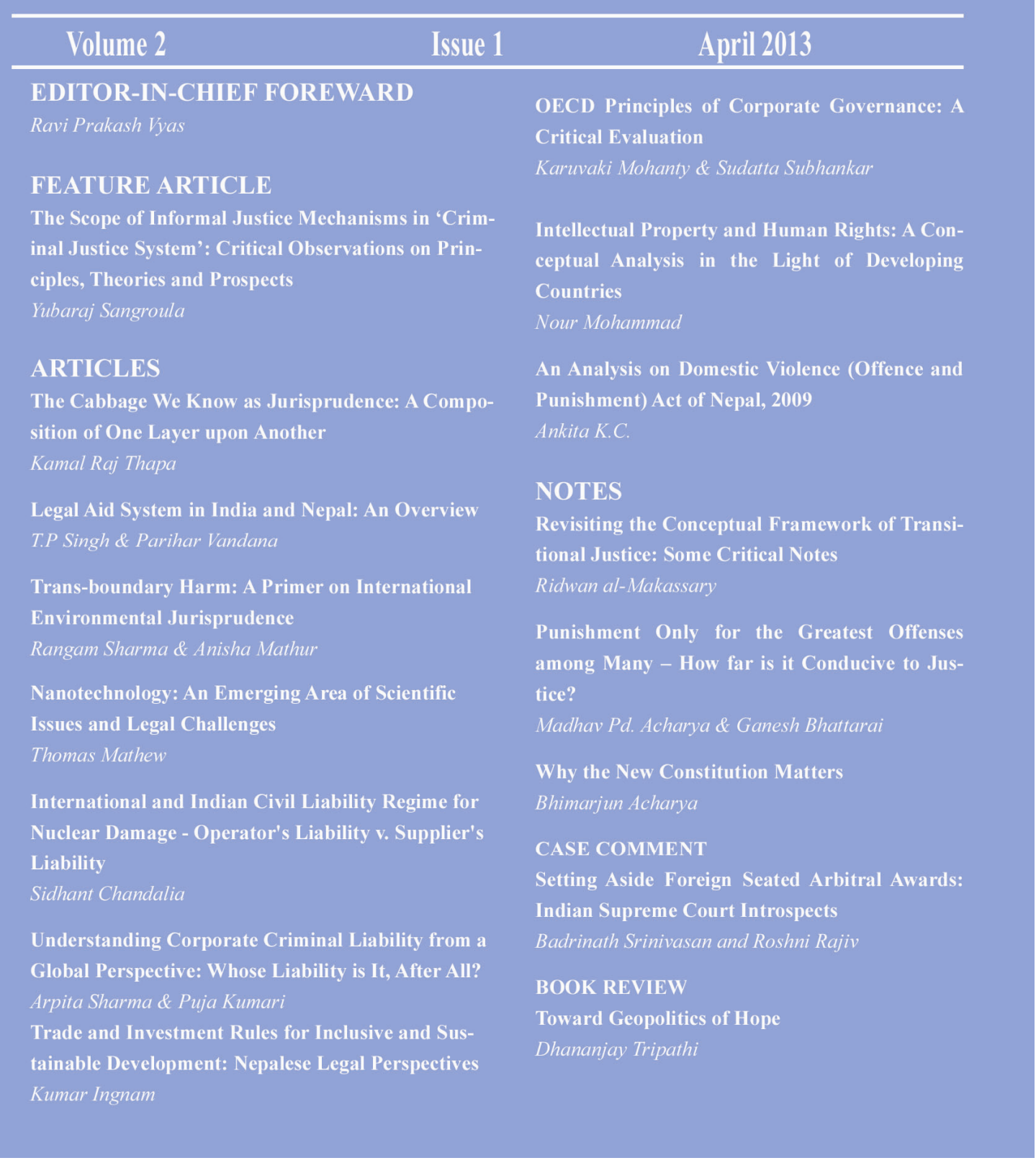




\title{
Why the New Constitution Matters
}

\author{
Dr. Bhimarjun Acharya ${ }^{1}$
}

\section{Adopting the New Constitution}

In every country, there are certain objectives for having a new constitution. One of the most common objects why the people desire a new constitution is that the people wish to make a fresh start in the prevailing system of governance by breaking up with the past. The circumstances in which a breakup with the past and the desire for a fresh start may come about vary from country to country. The historical instances which show how and when the desire or need for a fresh start arose commonly include the achievement of independence from an empire or colony, a category to which the best examples to be drawn would be the constitutions of the USA, India, Austria, Hungary and Czechoslovakia, to name a few. A revolution in order to make the break with the past or circumstances lead the people to desire formation of a new form of government on new forms of principles of governance, as exemplified by the French constitution of 1789, the Russian constitution of 1917 among others. Defeat in war makes the constitution of the government crumble necessitating a fresh start, as discernible in the German Constitution of 1918.

The need for reorganizing the political situation of the contemporary political system of a state may be another reason for adopting a new constitution. For instance, such a need arose in England in 1653, when Parliament, having created an army to obliterate the king, was itself obliterated by its own child. Consequently, the 'Instrument of Government', which made the Cromwell Lord Protector and established a new legislature, came into force as a (written) British constitution for a few years. Many of the post 90s constitutions happen to belong to this category.

Experiences and studies reveal that the constitution must be treated with respect if it its enduring longevity is aspired. A constitution does not attain legitimacy until it is treated with respect and tends to fast lose its legitimacy when abused or ignored. It is simply because each constitution whether new or old receives 'force of law' from the people. In the purview of these circumstances, Nepal illustrates the situations in which the contemporary context have led the people to desire disassociation with the bygone times. They have become cognizant about the face of Nepalese political system and political situation. The new constitution is hence needed in the changed context of Nepal to move away from the past ridden with the insurgency and other factors in the last decades.

\footnotetext{
${ }^{1}$ Advocate at Supreme Court of Nepal and Adjunct Faculty at Kathmandu School of Law, Nepal.
} 


\section{Making of the Constitution}

Constitution-making is a crucial step in the state building process as it enables to outline the vision of a new society, define the fundamental principles of a state and redistribute the power. This task is undertaken in many countries making the transition from conflict, oppression, or other major political crises. In post conflict times, constitution-making also becomes a vehicle for national dialogue and peace process. One of the innovations in such constitution-making practice is the evolution of a 'process-driven constitutionalism', which perceives that the process is equally important as the content of the final document for the legitimacy of a new constitution. This process is an exhortation to all the people to participate effectively so as to have true ownership of the final product.

In the aforesaid context, the processes involved, hither to, in making the constitution can mainly be divided into two kinds, namely, the so-called expert constitution-making process (the traditional approach) and the participatory constitution-making process (the new approach). The two approaches mark the significant differences in the process and outcome of a new constitution. There is also a fundamental distinction in the attitudes of these two processes. For instance, the new approach is based on the premise that for a constitution to be legitimate, it must have the support of the people. Without this legitimacy, there is less assurance that either the constitution or rule of law in general will be willingly accepted and internalized. Under this approach, participation is promoted as both a right and necessity. A claim of necessity for participation is based on the belief that without the general sense of ownership that comes from sharing authorship, the people will not respect and obey the constitution. The traditional approach is, in contrast, a conversation among all who are concerned; open to new entrants and issues, seeking a workable formula that will be sustainable rather than assuredly stable. The participatory constitution-making processes have been accomplished by massive efforts to involve the public before, during and after the text is finalized. In particular, the process of broad consultation and participation of the people is very much a prerequisite for making a democratic constitution. It is required at least to:

- legitimize the new constitution as people will feel that they were able to participate in the shaping of the basic law of their country. Consequently, they will morally as well as legally be obliged to obey the constitution.

- help to identify the real concerns of the people and aggregate their ideas, cover areas where a consensus has already been made.

- get educative effect allowing people to understand the issues to be decided by the constituent assembly or parliament.

- make it more difficult for a force claiming to speak in the name of the to hijack the constitution making process. 


\section{Basic Patterns of a Constitution}

Looking at the relationship among the contents of the constitution, the fundamental characters so involved and the making processes designed to the constitution, the pattern of constitutions can be categorized into four basic models:

Constitution as an embodiment of fundamental rules and basic rights: As an embodiment of fundamental rules, constitution sets up the framework of government, postulates how it ought to operate, delineates the basic structure, institutions and procedures of the polity, and as protector of citizens, it declares certain rights to be basic and provides means for their protection. This model of constitution is dominant in the English-speaking countries including the USA. The experiences reveal that the so-called expert constitution making process can produce this kind of constitution.

Constitution as a code: In contrast to the first pattern, this model perceives the constitution as a state code designed to cope with an established order. Constitutional change in the case of such constitutions reflects either a change in regime or the necessity to adapt the constitution to delineate precisely the ends of government at a given time. The constitutions of Austria and the German Federal Republic are classic examples of such highly rigid model. This model is mostly dominant in the continental European democracies.

Constitution as a manifesto of revolution: Most common in the Socialist or Communist states, this pattern of constitution is designed for the comprehensive revolutionary reconstruction of an established civil society, based upon the achievement of a social revolution of the most fundamental kind, with all of its political manifestations and impact. This is a constitution designed to root out the old order and to reorder its elements in their entirety. This model of a constitution is dominant in the former Soviet bloc countries.

Constitution as a common manifesto of the will and aspiration of people: This model is most closely identified with the Third World. This type of constitution combines an expression of what its citizens believe the regime should be with the basic structure of authority which will enable the current power holders to rule with a measure of legitimacy. This model defines constitution as a sort of manifesto, creed or testament; a confession of faith; a statement of ideals; an expression of the will and aspiration of the people and so on, and therefore the constitution, to this model, is not exclusively a legal document. It is rather a mixed of socio-political and legal document which invokes the respect and affection and, indeed, obedience of the people. Latin American and most of the Asian and African states are largely influenced by this model.

\section{Concluding Words}

The method that Nepal chose in making the constitution is essentially a part of participatory constitution making processes. It was done $t$ on the belief that without the general sense of ownership that comes from sharing authorship, the people will not respect and obey the 
new constitution. In the context, foremostly, the essence of participatory constitution making process as discussed above needs to be respected by Nepalese leaders and CA members if they desire that the constitution promulgated by CA should be owned by the people and be a long lasting document. Ideally a just constitution would be a 'just procedure' arranged to insure a 'just outcome'. The procedure would be the political process governed by the law, the outcome the body of enacted constitution. In Nepalese case with references to the past constitution making experiences, a successful outcome requires a focus not only on the final document which emerges, but on the path to producing and adopting it. Indeed, the constitution-making process can be a transformational one for societies, if properly organized and given adequate attention and sincerity. Among the described patterns of constitutions, the model of 'constitution as a national manifesto of the will and aspiration of people' will be moderated at least to ensure both the process and outcome of new constitution. Such model of constitution can envision not only political justice/democracy but also social and economic justice/democracy, hence would be a best suited with due respect to the will and aspiration of Nepalese people.

$* * * * * * * * * * * * * * * * * * *$ 